\title{
Gesture Visualization from Babad Diponegoro (UNESCO's MoW) into Digital Character using Motion Capture
}

\author{
Harry Nuriman ${ }^{1}$, Setiawan Sabana ${ }^{2}$, Intan Rizky Mutiaz ${ }^{3}$, Rikrik Kusmara \\ Andryanto ${ }^{4}$ \\ 1,2,3,4 Institut Teknologi Bandung, Indonesia \\ Email: harrynuriman@itb.ac.id
}

\begin{abstract}
The image of Prince Diponegoro as a national hero of Indonesia is very strong. However, there are controversies and myths regarding his characterization. The researcher deconstructs the character of Prince Diponegoro by appropriating Raden Saleh's painting entitled Penangkapan Pangeran Diponegoro by tracing the authentic script from the autobiography of Babad Diponegoro. The manuscript is examined using an intertextuality approach. Prince Diponegoro is constructed based on the physical characteristics contained in the Babad Diponegoro text into a three-dimensional digital model. The results are then rearranged using the deconstruction method by detaching from the existing stereotype of Prince Diponegoro and displaying his character and habits as written in Babad Diponegoro. A number of questions to be answered through this research are what can be visualized from the character of Prince Diponegoro using a textual approach, especially based on Babad Diponegoro, why does the character and identity based on Babad Diponegoro need to be visualized and what methods can be used to bring out the body and character. through the use of digital technology which includes embodiment, motion, gesture, sound, light, interactivity so as to provide a new experience for the audience. The result was a series of movements and visuals that enriched the characterization of Prince Diponegoro. All characters, both those that have been formed for a long time and those that were only known after the translation of Babad Diponegoro, were shown in the virtual experiment entitled Hikayat Dipanegara. The results showed that appropriation using different dimensions and technology resulted in a new image of Prince Diponegoro. The crossing of signs that occurs between real and virtual experiences and in the context of time can provide a new experience which may change the perspective or understanding of things.
\end{abstract}

Keywords: Animation, 3D Model, Gesture, Pangeran Diponegoro, Motion Capture.

\section{A. INTRODUCTION}

The term digitalization of the body or 'digitalization of the body', the digital body or 'the digital body', and the body as digital or 'the body as digital', refers to various aspects of the subject of new media, including the role of identity and gender. In new media and the culture in which the media are born and develop, the image and imagination of the body are always interesting themes. The large number of works of art that are born and grow in the realm of new media culture reflects the high attractiveness of this topic, and reflects the continuous development of technology.

To understand how digital media affects our senses and our bodies, we must consider the relationship between digital technology and the body (and all the 
positive representations that can be developed from this relationship) through ethical reflection (Fuery, 2009:84).

It is very likely that questions will arise about the "existence" of a "digitalized body", with an emphasis on how a particular description of the body in new media will test the limits of the presence of the body. The metaphorical perception of the existence of the electronic body is more textual and informational than as a real or corporeal being. Based on this metaphorical understanding, we can examine how the digitization of the body forces us to fragment the concept of the body and requestion and evaluate the function and importance of certain cultural practices and performances. This approach can also help identify the link between the body and the issues of digitality and materiality in relation to the formation of a new media culture (Fuery, 2009:84).

Visualization is defined as the expression of an idea or feeling using the form of pictures, writing (words and numbers), maps, graphics, and so on. Visuality is an image, both two-dimensional (two-dimensional) and three-dimensional (threedimensional) that can be identified through our optical senses (eyes). Twodimensional visual images can be in the form of paintings, posters, photography, book covers, bulletin boards and so on. The three-dimensional image can be in the form of a relief or a statue.

The body is one of the subject matters of fine arts and has been widely explored and visualized in two-dimensional art (such as painting) and threedimensional art (for example sculpture). As a unique medium because it can be moved, the body is often used to articulate messages to be conveyed aesthetically, for example in the form of theater, dance or pantomime.

The use of three-dimensional (3D) computer graphics technology has begun to penetrate many fields of art, including gestures such as dance and pantomime. The use of 3D technology is significant in conditions when the use of the body as a medium for expression is limited by physical factors. This limitation can be anticipated by using technology using computer graphics (3D modeling) and motion capture to digitize the body and the costumes and other equipment it uses.

The idea of taking advantage of digital body technology has been widely used in computer and military games. 3D animated films have been produced and a number of studies have been conducted, however, research that has focused on examining the digital body as a medium of expression and visual communication has so far not been done.

The body has an increasingly important role, especially regarding its existence, representation and diversification through various genres of new media. At the simplest level, framing the body as a "digital" form means that the body is "information". In other words, body-information.

The body has an increasingly important role, especially regarding its existence, representation and diversification through various genres of new media. At the simplest level, framing the body as a "digital" form means that the body is 
"information". In other words, the body information in a digital context - raises various problems and complexities.

Among the questions that might arise are regarding methods of communication and exchange (how information is socialized or positioned), identification (how to identify a digital body), and ethics (what implications are there for a "digital" body). Does our interaction with new media imply that we are a digital body or that we have become a digital body? Does the digital body have a material form or does its presence have to be in absentia? (Fuery, 2009:84).

Based on the description above, some questions arise about the relationship between the body in motion and new forms of media or technology, namely 3D technology using motion capture, and how the body is constructed in a new media culture. These questions are as follows:

1. What symptoms and semiotic elements related to the body (and embodiment or embodiment) can be found in the digital body?

2. How to digitally map the body so that a structured pattern can be created in $3 \mathrm{D}$ ?

3. What steps can be used and what elements related to the body and embodiments are important to emphasize when doing the digitizing (3D) process of the body?

In general, this research will explore the possibility of using 3D animation technology in computer graphics to compile a sign system on a digital body. For this research case study, the character of Pangeran Diponegoro will be completely digitized, then broken down into movement fragments and art objects that support him. After that an analysis will be carried out so that a digital model of the body of Pangeran Diponegoro will be created. With the creation of this digital model, researchers will be able to identify, develop, and build a system that can explore messages and / or noble values contained in the figure of Pangeran Diponegoro.

This research will be conducted with the aim of:

1. Identify and describe the symptoms and semiotic elements related to the body (and embodiment or embodiment) that can be found in a work and in the results of digitization (3D).

2. Describe in detail how a body is mapped so that a structured pattern can be created in 3D.

3. Describe the steps that can be used and the elements related to the body and embodiments that are important to emphasize when doing the digitizing (3D) process of the body pattern.

Previous research that has been done on the representation and connection between the body and new media has generally concentrated on how the body can be modified in a technological context. The body as information and the digitization of the body basically talk about digitizing information and modes of communication because these studies are a way to see the relationship and connection between corporeality and consciousness. Both aspects contain themes and modification issues both conceptually and practically (Fuery, 2009). 
The relationship between the body and technology is not a new issue in determining understanding of new socio-cultural practices. What cultural practices contribute to the digitization of the body, a great deal of determinism is required. For any position or location of the body and its representation in any medium, there are always many alternative understandings and interpretations. Disembodiment and embodiment theory can be used to analyze body virtualization (Fuery, 2009:90).

The concept of how thinking about how the body and embodiment are related lies in the ability to identify the social and cultural processes and practices that Hayles calls 'inscription' and incorporation. Based on the characteristics of contextual knowledge, habitual, hidden consciousness, and framing that allow embodiment incorporation, there are always changes and new technologies. When there is a shift in such practices, this shift is often manifested spatially and temporally. The symbiotic relationship between embodiment and technology lies in how Hayles differentiates between informatics materiality and information immateriality or how technological changes have changed the mode of embodiment (Hayles, 1999). The latest technological development that has become the object of many studies related to the body, specifically the body that moves, is the use of new 3D (3-dimensional) media. The study of the body in motion can be carried out as a comparative study of symbolic systems based on language, visual representations, and motion (Desmond, 1999).

\section{B. METHOD}

Referring to the questions in the PROBLEM FORMULATION and THEORETICAL FRAMEWORK that was proposed, the use of digital bodies is very helpful in overcoming the limitations of artists to express themselves. However, how the body and technology, in this case digital technology, influence each other. When a body that moves, a body that dances, is codified into a 3D image, there will be a shift or change, including what is the focus in the process of combining the body and technology.

Studying the digitization of the body is more than just questioning how digital and electronic technologies that form new media have an impact and influence on the role and function of the body and the embodiment of artists. The assumption is that not all body sign systems of the artist's body, or the value systems contained in a work, can be visualized accurately with the same representation, meaning and effect when transformed into a digital body.

A method is a systemized way of working that facilitates the implementation of an activity to achieve specified goals. For this research, the method to be used is an objective or descriptive method that is closely related to the qualitative methods that are widely used in research in the humanities and arts sciences. The use of this method aims to present data from the point of view of the research subject or group being observed, so that cultural and intellectual obscurity from the researcher will not interfere with the collection, interpretation and explanation of data (Seliger and Shohamy, 1987). 
In this study, data collection will be carried out through a study of a literary work of Babad Diponegoro. The data obtained will be analyzed using qualitative data analysis techniques. To analyze the data obtained from the results of data collection, the semiotic method of Yasraf A Piliang will be used, namely to identify and analyze the sign systems found on a moving body, both in the form of conventional performances and the results of digitization. The body of Pangeran Diponegoro will be reviewed in detail in relation to the sign system and its representation. Regarding the sign system, a narrative descriptive analysis of the artist's body will be used using Foucault's theory.

\section{RESULT AND DISCUSSION}

For the manufacture of a 3-dimensional digital body model, experimental methods using computer graphics and Motion Capture techniques will be used. Motion Capture or often abbreviated as MOCAP is a technology for making animated films using a motion recorder. The recorded movements are then converted into a digital form of movement. This process is carried out by recording the movements of the dancer whose body has been affixed with a marker. The resulting digital files will later be used to drive the character models that have been made previously in 3-dimensional applications.
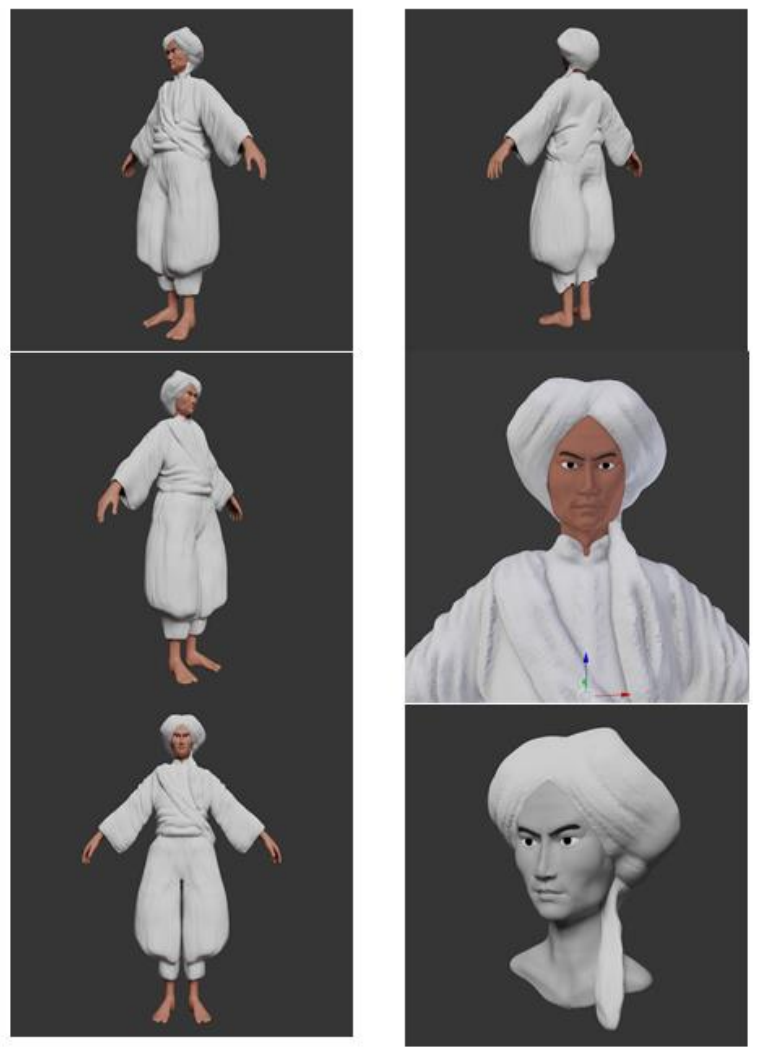

Figure 1 Digital 3D model of Pangeran Diponegoro based on Babad Diponegoro

In Motion Capture, the movements of a model are sampled many times per second. This Motion Capture only records the movements of the model, not the visual appearance. The recorded movement data is then mapped into a 3- 
dimensional model so that the model performs the same movements as the movements made by the model.

For the MOCAP process, a reflective marker is placed on a special costume to mark the location of the bones and the 3-dimensional motion of the body. For the process of taking body motion data. the model uses special equipment that has been given a chip with bluetooth technology. The captured model's motion data is then displayed on the screen in the form of vectors. The model's motion is then applied to the digital body (3D model), complete with costumes and other accessories.

\section{CONCLUSION}

Based on the results of the research and discussion described in the previous chapter, it can be concluded that the visual construction of a character that is built based on text can give a new impression to the image of a character that previously felt monotonous because it was not based on authentic evidence. The use of various contemporary technologies makes the delivery of messages in works more effective and provides new experiences for the audience. It answers the epistemological questions of the research conducted.

The results showed that appropriation using different dimensions and technology resulted in a new image of Pangeran Diponegoro. The multidimensional visual construction of a character built on the basis of text can give a new impression to the previously constructed character image.

This is axiologically useful to complement the existing characters so that the figure of Pangeran Diponegoro is more complete and realistic. The use of various contemporary technologies makes the delivery of messages in works more effective and provides new experiences for the audience.

Research shows that interactive performance art is not only a presentation of virtual reality, augmented reality, mixed reality, but a new combination of these. The crossroads that occur between real experiences and everything that is presented through the use of virtual reality, augmented reality, mixed reality will be experienced by artists, actors, players or audiences and provide a new experience that may change the perspective or understanding of a character like Prince Diponegoro.

\section{REFERENCES}

1. Aristidou, A., Charalambous, P., \& Chrysanthou, Y. (2015, September). Emotion analysis and classification: understanding the performers' emotions using the LMA entities. In Computer Graphics Forum (Vol. 34, No. 6, pp. 262-276).

2. Ardison, M. S. (2017). Diponegoro E Perang Jawa. Jakarta: Ecosystem Publishing.

3. Badi, H. S., \& Hussein, S. (2014). Hand posture and gesture recognition technology. Neural Computing and Applications, 25(3), 871-878.

4. Carey, P. B. (1982). Raden Saleh, Dipanagara and the Painting of the Capture of Dipanagara at Magělang (28 March 1830). Journal of the Malaysian Branch of the Royal Asiatic Society, 55(1 (242), 1-25. 
5. Carey, P. B. (2015). Kuasa Ramalan Jilid 1. Jakarta: Gramedia.

6. Carey, P. B. (2017). Takdir Riwayat Pangeran Diponegoro (1785-1855). Jakarta: Kompas.

7. Carey, P. B. (1987). Kesatria dan Santri: Beberapa Catatan Tentang Hubungan Pendukung Keraton and Agamawi Diponegoro, sari Babad dan hikayat sampai sejarah kritis. Yogyakarta: Gadjah Mada University Press.

8. So, C. K., \& Baciu, G. (2005). Entropy-based Motion Extraction for Motion Capture Animation. Computer Animation and Virtual Worlds, 16(3-4), 225-235.

9. Courty, N., \& Corpetti, T. (2007). Crowd motion capture. Computer Animation and Virtual Worlds, 18(4-5), 361-370.

10. Creswell, J. W., (2016). Research Design, Pendekatan Metode Kualitatif, Kuantitatif, dan Campuran. Yogyakarta: Pustaka Pelajar.

11. Desmond, J. S. (1997). Meaning in Motion: New Cultural Studies of Dance (Post Contemporary Interventions). New York: Duke University Press.

12. Djamhari, S. A. (2014). Strategi menjinakkan Diponegoro: Stelsel Benteng 1827-1830, Depok: Komunitas Bambu.

13. Djelantik, A. A. M. (2001). Estetika Sebuah Pengantar: Bandung: MSPI (Masyarakat Seni Pertunjukan Indonesia).

14. Djordjevic, N. (2014). The Depiction of a (National) Hero: Pangeran Diponegoro in Paintings from the Nineteeth Century until Today. Surakarta: Master Thesis UNS.

15. Flick, U., Steinke, I., \& Kardoff, E. V. (2017). Buku Induk Penelitian Kualitatif: Paradigma, Teori, Metode, Prosedur, dan Praktik. Yogyakarta. Cantrik Pustaka.

16. Fuery, K. (2009). New Media: Culture and Image. New York: Palgrave Macmillan.

17. Ghori, A. K., \& Chung, K. C. (2007). Interpretation of hand signs in Buddhist art. The Journal of hand surgery, 32(6), 918-922.

18. Gunawan. (2016). Babad Dipanegara. Yogyakarta: Narasi.

19. Guntur. (2016). Metode Penelitian Artistik. Surakarta: ISI Press.

20. Hardiman, F. B. (2015). Seni Memahami. Yogyakarta: Kanisius.

21. Hashi, S., Tokunaga, Y., Yabukami, S., Kohno, T., Ozawa, T., Okazaki, Y., ... \& Arai, K. I. (2005). Wireless motion capture system using magnetically coupled LC resonant marker. Journal of magnetism and magnetic materials, 290, 1330-1333.

22. Hayles, N. K. (1999). How We Became Post Human: Virtual Bodies in Cybernetics, Literature, and Informatics. Chicago: Univ. of Chicago Press.

23. Kartodirdjo, S. (1992). Pendekatan Ilmu Sosial dalam Metodologi Sejarah. Jakarta: Gramedia

24. Kimmel, M., \& Preuschl, E. (2016). Dynamic Coordination Patterns in Tango Argentino: A Cross-Fertilization of Subjective Explication Methods and Motion Capture. Springer International Publishing Switzerland.

25. Kitagawa, M., \& Windsor, B. (2008). MoCap for Artists. Oxford: Elsevier.

26. Kraus, W. (2005). Raden Saleh's Interpretation of The Arrest of Diponegoro an Example of Indonesian "Proto-nationalist" Modernism. Archipel, 81(1/2).

27. Laumond, J. P., \& Abe, N. (Eds.). (2016). Dance Notations and Robot Motion. Springer International Publishing. 
28. Lazzeri, D., Xi, W., Zhang, Y. X., \& Persichetti, P. (2014). A systematic reappraisal of the fifth finger in Renaissance paintings. Journal of the Royal Society of Medicine, 107(12), 474-479.

29. Liu, X., Mao, T., Xia, S., Yu, Y., \& Wang, Z. (2008). Facial animation by optimized blendshapes from motion capture data. Computer Animation and Virtual Worlds, 19(3-4), 235-245.

30. Louw, P. J. F. (1894). De Java Oorlog van 1825-1830. Batavia: Landsdrukkerij.

31. Mirzoeff, N. (1999). An Introduction to Visual Culture. London: Routledge.

32. Moeslund, T. B., \& Granum, E. (2001). A Survey of Computer Vision-Based Human Motion Capture. Computer Vision and Image Understanding 81, 231-268.

33. Moeslund, T. B., Hilton, A., \& Kruger, V. (2006). A survey of advances in visionbased human motion capture and analysis. Computer Vision and Image Understanding, 104, 90-126.

34. Nuriman, H., Sabana, S., Mutiaz, I. R., \& Kusmara, R. A. (2020). From Real to Virtual: Adaptation Model of Performance Arts during Covid-19 Period. Jurnal Sosioteknologi, 19(2), 162-169.

35. Palmer, R. E. (1969). Hermeneutika Teori Baru Mengenai Interpretasi. Yogyakarta: Pustaka Pelajar.

36. Papadakis, A. (1989). Dekonstruksi: Volume Omnibus. London: Academi Editions.

37. Pettre, J., \& Laumond, J. P. (2006). A motion capture-based control-space approach for walking mannequins. Computer Animation and Virtual Worlds, 17(2), 109-126.

38. Piliang, Y. A. (1998). Sebuah Dunia yang Dilipat. Bandung: Mizan.

39. Rahmatalla, S., Xia, T., Contratto, M., Kopp, G., Wilder, D., Law, L. F., \& Ankrum, J. (2008). Three-dimensional motion capture protocol for seated operator in whole body vibration. International Journal of Industrial Ergonomics, 38(5-6), 425-433.

40. Ram, A. N., \& Chung, K. C. (2008). Study of hand signs in Judeo-Christian art. The Journal of hand surgery, 33(7), 1182-1188.

41. Royle, N. (2003). Derrida. London: Routledge.

42. Sabana, S. (1999). Catatan Diri dalam Kertas. Retrieved from: http://www.setiawansabana.com/home/?page id=140

43. Schneider, A. (2007). Appropriation as practice: art and identity in Argentina. Springer.

44. Simatupang, L. (2015). Aku Diponegoro. Jakarta: Gramedia.

45. Sumardjo, J. (2000). Filsafat Seni. Bandung: ITB.

46. Tang, J. K., Chan, J. C., \& Leung, H. (2011, February). Interactive dancing game with real-time recognition of continuous dance moves from 3D human motion capture. In Proceedings of the 5th international conference on ubiquitous information management and communication (pp. 1-9).

47. Thüring, S., Herwig, J., \& Schmitt, A. (2005). Silhouette-based motion capture for interactive VR-systems including a rear projection screen. Computer Animation and Virtual Worlds, 16(3-4), 245-257. 
48. Van der Kroef, J. M. (1949). Prince Diponegoro: Progenitor of Indonesian Nationalism. The Far Eastern Quarterly, 8(4), 424-450.

49. Vincs, K., \& Barbour, K. (2014). Snapshots of complexity: using motion capture and principal component analysis to reconceptualise dance. Digital Creativity, 25(1), 62-78.

50. Wu, L., Yang, Y., \& Li, X. (2015, August). Data Transform for Dance Motion Capture Based on Kinect. In 2015 7th International Conference on Intelligent Human-Machine Systems and Cybernetics (Vol. 2, pp. 108-111). IEEE.

51. Yahia-Cherif, L., Gilles, B., Molet, T., \& Magnenat-Thalmann, N. (2004). Motion capture and visualization of the hip joint with dynamic MRI and optical systems. Computer Animation and Virtual Worlds, 15(3-4), 377-385. 